\title{
Isolation and Characterization of New Compound and its Antibacterial Activities from Stem-Bark Extract of Barringtonia Asiatica
}

\author{
Isaac John Umaru1,2*, Hauwa A Umaru ${ }^{3}$ and Kerenhappuch I Umaru ${ }^{4}$ \\ ${ }^{1}$ Faculty of Resource Science and Technology, University of Malaysia Sarawak, Malaysia \\ ${ }^{2}$ Department of Biochemistry Federal University, Nigeria \\ ${ }^{3}$ Department of biochemistry, Modibo Adama University of Technology, Nigeria \\ ${ }^{4}$ Department of biochemistry, University of Maiduguri, Nigeria
}

\section{Research Article \\ Volume 2 Issue 2}

Received Date: August 08, 2019

Published Date: August 27, 2019

DOI: $10.23880 /$ aabsc-16000140

*Corresponding author: Isaac John Umaru, Faculty of Resource Science and Technology, University of Malaysia Sarawak, Kota Samarahan Malaysia. Email: umaruisaac@gmail.com

\section{Abstract}

Objective: This investigation involves the extraction, isolation, and characterization of chemical constituents from a Barringtonia family plant, Barringtonia asiatica followed by Antibacterial, cytotoxicity and evaluation of its antioxidant principles.

Methods: The dried stem-bark powders were subjected to sequential soaking with polar and nonpolar solvents and extraction using rota-vap. Dichloromethane extract reveals the presence of significant amount of phytochemicals. The dichloromethane extract was subjected to isolation using column chromatographic analysis with solvents such as, dichloromethane, chloroform, hexane, ethyl acetate and methanol. Further, the isolated compound was subjected to thin layer chromatography technique and spectral analysis such as infrared, ${ }^{1} \mathrm{H}-\mathrm{NMR},{ }^{13} \mathrm{C}-\mathrm{NMR}$, FT-IR, and mass spectroscopy. The antibacterial using agar disc method.

Results: The compound was isolated in hexane: ethyl acetate (9:1) and dichloromethane: ethyl acetate in the solvent system in the ratio of 9:1 and 7:3, respectively using column chromatographic technique. On the basis of phytochemical, chromatographic, and spectral analysis, the isolated compounds were identified as Nerolidiol and Heneicosane.

Conclusion: This compound was isolated for the first time from the stem-bark of Barringtonia asiatica. The in vitro antioxidant assay of isolated compounds has shown a dose-dependent increase in free radical scavenging activity using DPPH, the antibacterial and artemia salina cytotoxicity testing showed a significant result. The chromatographic separation led to the isolation of Nerolidiol (1) and Heneicosane (2). Their structures were determined by ${ }^{1} \mathrm{H}-\mathrm{NMR},{ }^{13} \mathrm{C}-$ NMR, IR and MS data analysis as well as by comparison of their data with the published values. 
Keywords: Isolation; Characterization; Phytochemicals; Stem-bark; Barringtonia asiatica; Antioxidant; Cytotoxicity; Antibacterial

\section{Introduction}

Focus on medicinal plant research has increased worldwide and evidence abounds in the immense potentials of medicinal plants such as Barringtonia asiatica used in various traditional systems. Various medicinal plants have been studied using different scientific approaches and results from these studies have revealed the potentials of medicinal plants in pharmacology [1]. This medicinal plant Barringtonia asiatica is of great importance to the health of the individuals and communities to larger extend, and nutritional benefits are derived from these plants since they are commonly used as vegetables.

The search for new drugs worldwide has become a necessary tool due to so many health challenges arising from resistant species of diseases causative agents and discovery of different species and trends of bacteria and viruses. These have therefore turned researchers to plant sources for the active phytochemicals that could combat these new trends in health challenges; thus, plants hold the key to the discovery and development of new pharmaceutical and biological resources that will champion the course of health and well-being of human. These various plants on which human and animal's life depend on for food contains thousands of phytochemicals and allelochemicals [2] which constitute anti-nutritional or beneficial factors to the consumer. It was therefore observed from outcome of research works that the medicinal value of these plants and medicinal plants lies in some chemical substances that produces a definite physiological action on human body.

Thus, the use of medicinal plants in the world traditional medicine has been in practice for a long time, and the practice is now becoming increasingly popular, especially as an alternative or as a compliment to modern medicines [3]. They have been used in various traditional medicinal practices especially for the treatment of cancer, cardiovascular diseases, hypertension, ulcer, rheumatic disease, asthma and other health problems [4]. The medicinal activities of the plants have long been associated with the production of secondary metabolites which includes tannins, terpenoids.

Also searching for new lead compounds to be developed as drugs or as templates for analogue synthesis and the evaluation of traditional medicine and herbal medicinal products, are the two basic reasons for the advancement of work on medicinal plants. This could also be partly justified by the fact that natural product inspired molecules represented about $80 \%$ of drugs that had been put into the market $[5,6]$.

The Aim of this study was in order to isolate chemical compounds and to test the biological activity of the isolated compounds. Thus, the vast medicinal potentials of Barringtonia asiatica have not been explored as seen from literature survey. Not much work has been reported on the isolation of chemical compounds as well as biological activity of the isolated compound from the stem-bark of Barringtonia asiatica.
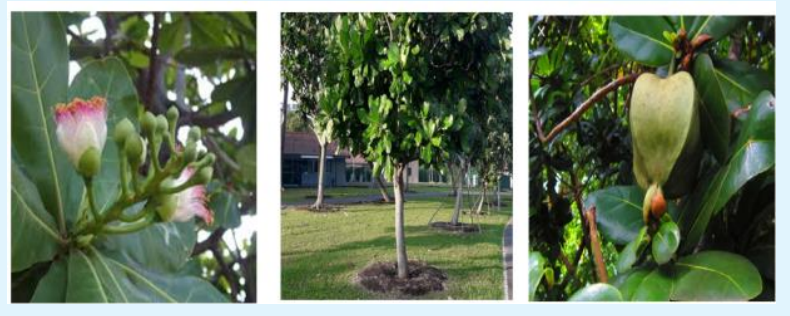

Figure 1: Showing the flower, tree (stem-bark) and the fruit of Barringtonia asiatica.

\section{Material and Methods}

\section{Plant Material}

Sample Collection: Fresh plant material was collected from Merenak river bank at Kota-Samarahan, Sarawak Malaysia. The plant was authenticated by a Botanist in the Faculty of Resource Science and Technology, Universiti Malaysia Sarawak. The identified and certified plant materials were given a voucher number as IJU15010238 (Barringtonia asiatica stem-bark. The fresh stem-bark from the plant was carefully pealed and washed under running tap water. It was then air dried to be free of water and cut into smaller pieces, then spread in the laboratory and allow to dry at room temperature until they were fully dried.

Sample Preparation: Dried plant materials (stem-bark) were ground into fine powder form using laboratory 
pestle and mortar and electric grinder. The finely ground powdered samples (mesh 30) were packed into clean, dry sample containers and were labelled appropriately and kept for further use. Extraction was carried out by the conventional solvent extraction method described by Fasihuddin et al. [7]. This was achieved by soaking the ground plant material in solvents in the order of increasing polarity. A total of $2 \mathrm{~kg}$ of the dried and ground powdered sample was extracted using cold soaking method with hexane. The sample were soaked in the hexane with the ratio of 1:3 (sample: hexane) in a 5 liters Erlenmeyer flasks at room temperature for 5-7 days. The resulting hexane solution was then filtered using Whatman filter paper No 4 and the residue was then reextracted with fresh hexane for another $72 \mathrm{hrs}$ and filtered. Both extracts were combined and evaporated to dryness with a rotary evaporator (Heidolph Laborota 4000 efficient) under reduced pressure below $50^{\circ} \mathrm{C}$ to obtain the hexane crude extract. The residue was reextracted using similar procedure with dichloromethane, followed by chloroform, ethyl acetate and methanol to obtain respective crude extracts. The dry weight and percentage yield of each crude extract were determined (simple percentage) [8].

\section{Isolation and Identification of Secondary Metabolites}

\section{Isolation and Purification}

Column chromatography: The basic principle of column chromatography is to separate a mixture of metabolites based on their molecular weight and polarity. A glass column of size 40/34 (large) was used for chromatography, and the sorbent used was silica gel 60 (Merck 70-230 Mesh ASTM $0.0630 .200 \mathrm{~mm}$ ). Silica gel slurry was prepared by dissolving silica gel $(150 \mathrm{~g})$ with suitable solvent, usually hexane. The column was prepared by pouring a slurry mixture of silica gel and solvent, into a glass column and allows it to settle down [9]. The packed column was left overnight before 4-10 g of sample was introduced onto the top of the packed column via wet-packing method or dry-packing method. The column was eluted with suitable solvent systems with increasing polarity [7]. The column's valve was then opened and about 10-30 mL fraction of the solvent coming out from the column was collected in test tubes [10]. The procedure was repeated by using different solvent systems, based on increasing polarity (Table 3.1). Samples from the column fractions were examined by using TLC plates in few suitable solvent systems to obtain the retention factor $\left(\mathrm{R}_{\mathrm{f}}\right)$ of any components that appeared as spots. Fractions with similar $\mathrm{R}_{\mathrm{f}}$ values were combined [10]. Fractions which contain more than one component were further isolated and purified by using smaller glass column of sizes $24 / 29$ (medium) or $14 / 23$ (small) with suitable solvent systems.

Fraction with single component (one spot) that appeared in TLC plate was treated as possible pure secondary metabolite. The combined fractions which contained the same single component was then allowed to air-dried or evaporated to dryness to obtain a pure secondary metabolite.

\begin{tabular}{|c|c|c|c|}
\hline $\mathbf{S} / \mathbf{n}$ & Solvent & Volume to volume ratio (v/v) & Volume (mL) \\
\hline 1 & Hexane & 1 & 400 \\
\hline 2 & Hexane: DCM & $19: 1$ & 400 \\
\hline 3 & Hexane: DCM & $15: 1$ & 400 \\
\hline 4 & Hexane: DCM & $9: 1$ & 400 \\
\hline 5 & Hexane: DCM & $5: 1$ & 400 \\
\hline 6 & Hexane: DCM & $1: 1$ & 400 \\
\hline 7 & DCM & 1 & 400 \\
\hline 8 & DCM: $\mathrm{CHCl}_{3}$ & $19: 1$ & 400 \\
\hline 9 & DCM: $\mathrm{CHCl}_{3}$ & $15: 1$ & 400 \\
\hline 10 & DCM: $\mathrm{CHCl}_{3}$ & $9: 1$ & 400 \\
\hline 11 & DCM: $\mathrm{CHCl}_{3}$ & $5: 1$ & 400 \\
\hline 12 & DCM: $\mathrm{CHCl}_{3}$ & $1: 1$ & 400 \\
\hline 13 & $\mathrm{CHCl}_{3}$ & 1 & 400 \\
\hline 14 & $\mathrm{CHCl}_{3}: \mathrm{EA}$ & $19: 1$ & 400 \\
\hline 15 & $\mathrm{CHCl}_{3}: \mathrm{EA}$ & $15: 1$ & 400 \\
\hline 16 & $\mathrm{CHCl}_{3}: \mathrm{EA}$ & $9: 1$ & 400 \\
\hline 17 & $\mathrm{CHCl}_{3}: \mathrm{EA}$ & $5: 1$ & 400 \\
\hline 17 & $\mathrm{CHCl}_{3}: \mathrm{EA}$ & $1: 1$ & 400 \\
\hline
\end{tabular}




\section{Annals of Advanced Biomedical Sciences}

\begin{tabular}{|l|c|c|c|}
\hline 18 & $\mathrm{EA}$ & 1 & 400 \\
\hline 20 & EA: $\mathrm{MeOH}$ & $19: 1$ & 400 \\
\hline 21 & EA: $\mathrm{MeOH}$ & $15: 1$ & 400 \\
\hline 22 & EA: $\mathrm{MeOH}$ & $9: 1$ & 400 \\
\hline 23 & EA: $\mathrm{MeOH}$ & $5: 1$ & 400 \\
\hline 24 & EA: $\mathrm{MeOH}$ & $1: 1$ & 400 \\
\hline 25 & $\mathrm{MeOH}$ & 1 & 400 \\
\hline
\end{tabular}

Table 1: Organic solvent systems used as eluting solvents for column chromatography.

DCM: dichloromethane, $\mathrm{CHCl}_{3}$ : chloroform, EA: ethyl acetate, $\mathrm{MeOH}$ : methanol.

Thin Layer Chromatography (TLC): The eluents collected from column chromatography, were subjected to thin layer chromatography (TLC) analysis. TLC was carried out using the method described by Isaac et al. [11]. A glass capillary tube was used to apply samples on the TLC plates (size $6.6 \times 20 \mathrm{~cm}, 5 \times 20 \mathrm{~cm}$ ) repeatedly with a spot of about $0.3 \mathrm{~mm}$ in diameter. The TLC plate was then placed in a rectangular glass developing chamber with its lower marked edge $(1 \mathrm{~cm}$ from the base) dipped into a developing solvent below the mark where the samples were spotted. The plates were allowed to develop to the level of upper mark ( $4 \mathrm{~cm}$ from the base) and then removed and dried. The TLC plates were then viewed directly for colored compounds, it was also viewed under UV box for UV fluorescent compound and stained with vanillin for compound that are neither visible nor UV fluorescence. Fractions containing similar characteristics were combined and dried.

\section{Chemical Structure Elucidation}

Gas Chromatography-Mass spectrometry (GC-MS): Gas chromatography (GC) analysis of fractions that were obtained from TLC as single spot was performed using a Shimadzu GC-Mass Spectrometry model QP2010 plus, equipped with a BPX-5 column (5\% phenyl polysylphenlenesiloxane) of $30 \mathrm{~m}$ in length, film thickness of $0.25 \mu \mathrm{m}$ and internal diameter of $0.25 \mathrm{~mm}$. The operating method was based on the method described by Kalaiselvan et al. (2012). Ionization energy of $70 \mathrm{eV}$ was used in the electron ionization energy system of the GCMS for detection and carrier gas, helium (99.999\%) at a constant flow rate of $1 \mathrm{~mL}$ per min was used. Exactly $1 \mu \mathrm{L}$ of purified sample was injected into the GC-MS using a syringe and sample was analyzed using split mode with ration of $25: 1$. Injection temperature was set at $260^{\circ} \mathrm{C}$ and the oven temperature was programmed from $60^{\circ} \mathrm{C}$ with an increase of $10^{\circ} \mathrm{C}$ per min, isothermal for $5 \mathrm{~min}$, to $280^{\circ} \mathrm{C}$, ending with $10 \mathrm{~min}$ isothermal at $280^{\circ} \mathrm{C}$ at $70 \mathrm{eV}$. A mass spectrum was taken at a scan interval of $0.5 \mathrm{sec}$ and fragments from 45 to $450 \mathrm{Da}$. By matching its average peak area to the total areas, the relative percentage quantity of each component was acquired. Compound identification was obtained by matching the retention times of the compounds and the mass spectral obtained from the library data of the corresponding compound.

Fourier Transform Infra-Red Spectrometry (FT-IR): Fourier Transform Infra-Red (FT-IR) was performed using FTIR spectroscopy (Thermos Scientific, Nicolet iS10 SMART iTR) to detect the chemical bonds (functional groups) of the compounds. The operating system was based on the method described by Shalini and Sampathkumar [12]. The liquid samples were introduced into the machine and scan range was set from 400 to $4000 \mathrm{~cm}^{-1}$ with a resolution of $4 \mathrm{~cm}^{-1}$. Characteristic of the chemical bonds was read by spectrum produced through transmittance of wavelength of light. The chemical bond in a molecule was detected by interpreting the infra-red transmittance spectrum and the functional groups of the compounds were identified based on the Table of Characteristic IR absorptions published in Organic Chemistry [3].

Nuclear Magnetic Resonance (NMR): Nuclear Magnetic Resonance (NMR) spectrometry was performed using JEOL JNM-ECA 500 Spectrometer. The operating system was based on the method described by Efdi, et al. [14]. Sample was dissolved in $0.8 \mathrm{~mL}$ chloroform D1 $\left(\mathrm{CDCl}_{3}\right)$ or Acetone D6 and placed into NMR tube to a sample depth of $4 \mathrm{~cm}$ and the ${ }^{1} \mathrm{H}(500 \mathrm{MHz})$ and ${ }^{13} \mathrm{C}(125 \mathrm{MHz})$ spectra were measured. Chemical shifts were reported as $\delta$ units (ppm) with tetramethysilane (TMS) as internal standard and coupling constants $(U)$ in $\mathrm{Hz}$. Integration of the ${ }^{1} \mathrm{H}$ NMR and ${ }^{13} \mathrm{C}$-NMR data was performed by using DELTA version 5.0.4 software by JEOL. The identification of each ${ }^{1} \mathrm{H}-\mathrm{NMR}$ and ${ }^{13} \mathrm{C}$-NMR detected was based on the Table of Characteristic NMR absorptions published in Organic Chemistry [13] and with the guide of the possible proposed structure given by NIST library.

Melting Point: The melting point of the compounds isolated was determined using a melting point apparatus (Stuat model SMP3). Small amount of the sample was put 
into a small capillary tube and was inserted into the machine melting point heating bath. The heating process was monitored and the temperature at which the sample begins to melt and completely melted was recorded.

\section{Biological Activity}

Brine shrimp (Artemia salina) Lethality Test: The $\mathrm{LC}_{50}$ of the plant extracts was determined using brine shrimp lethality test. The test was conducted using larvae of Artemia salina based on method developed by McLaughlin, et al. [15] and Isaac, et al. [16]. One spatula full of brine eggs was placed into a $250 \mathrm{~mL}$ beaker containing $150 \mathrm{~mL}$ of sea water placed under light environment. A source of $\mathrm{O}_{2}$ supply was connected to the beaker using water pump at reduced pressure and allowed for 72 hrs to hatch. The brine shrimp (nauplii) were then used for the test. Exactly $4 \mathrm{mg}$ of each extract was dissolved in $200 \mu \mathrm{L}$ of DMSO (RCI Labscan limited) and a lower series of chosen concentration was prepared by serial dilution with DMSO. The assay system was prepared with $5 \mathrm{~mL}$ of filtered seawater containing chosen concentration of extract and $1 \%$ yeast extract (for feeding) in a pre-marked 6-well microplate and 10 brine shrimps were carefully taken with micropipette and introduced into each microplate. This was done in triplicates making a total of 30 brine shrimps per concentration. Filtered seawater was added to DMSO and 10 brine shrimps in triplicates and this was used as the control groups. If the brine shrimp in these microplates shows a rapid mortality rate, then the test is considered invalid as the nauplii might have died due to some reasons other than the cytotoxicity of the extracts. The setup was allowed to remain for $24 \mathrm{hrs}$ under constant illumination of fluorescent and number of survived nauplii were counted with a hand lens. Based on the data obtained, the average death of the brine shrimp at different concentrations of the extract and the $\mathrm{LC}_{50}$ of the extract was calculated using probit regression by statistical software SPSS 22 and the result was expressed as mean + SD at the $95 \%$ level of confidence $(p<0.05)$.

DPPH (2,2-diphenyl-1-picryl-hydrazyl) Free Radical Scavenging Assay (Antioxidant): The free radical scavenging assay of compound 2,2-diphenyl-1-pycrylhydrazyl (DPPH) was used to evaluate the antioxidant properties of the crude extract. The measurement was based on the method described by Wang, et al. [17]. The sample was prepared by diluting $6 \mathrm{mg}$ of crude extract into $6 \mathrm{~mL}$ of methanol, producing a concentration of 1000 $\mu \mathrm{g} / \mathrm{mL}$. The stock solution was sonicated to ensure the homogeneity of the sample. Three other concentrations were prepared at 10,50 and $100 \mu \mathrm{g} / \mathrm{mL}$, diluted from the
$1000 \mu \mathrm{g} / \mathrm{mL}$ stock solution. Sample of $5000 \mu \mathrm{g} / \mathrm{mL}$ was prepared separately by diluting $25 \mathrm{mg}$ of crude extract into $5 \mathrm{~mL}$ of methanol.

Approximately $3 \mathrm{~mL}$ of $0.1 \mathrm{mM}$ solution of 2,2diphenyl-1-pycrylhydrazyl (DPPH) in methanol was each added into five series of prepared concentrations $(10,50$, $100,1000$ and $5000 \mu \mathrm{g} / \mathrm{mL})$ of sample solutions $(1 \mathrm{~mL})$. Analysis was done in triplicate. The solution was mixed vigorously and left to stand at room temperature for 30 minutes in the dark after which its absorbance was measured spectrophotometric ally at $517 \mathrm{~nm}$ using Jasco ultra violet spectrophotometer model V-630. Methanol was used as blank (only methanol) and negative control (1 mL methanol mixed with $3 \mathrm{~mL}$ DPPH), while ascorbic acid (vitamin C) as the standard. The concentration of the sample required to inhibit $50 \%$ of the DPPH free radical was calculated as $\mathrm{IC}_{50}$ and the value was determined using Log dose inhibition curve which performed by using PRISM version 3.02 software, based on the calculated values of the DPPH scavenging activity (\%) of the sample [18].

\section{Antimicrobial Activity Antibacterial Assay}

Test Microorganisms: Bacterial strains Escherichia coli (E. coli), Salmonella typhii (S. typhii) and Staphylococcus aureus (S. aureus) were selected for the study. The bacterial strains were obtained from the Microbiology Laboratory, Faculty of Resource Science and Technology, University Malaysia Sarawak, and were used for the antibacterial activities. The stock cultures were incubated at $37^{\circ} \mathrm{C}$ for $24 \mathrm{hrs}$ on nutrient agar (Micro care Laboratory, Surat, India), and was stored at $4^{\circ} \mathrm{C}$. Plates containing Mueller-Hinton Agar (MHA) were used to grow the bacterial strains at $37^{\circ} \mathrm{C}$. The stock cultures were then kept at $4{ }^{\circ} \mathrm{C}$ until use.

Antibacterial assay: Antibacterial activity of stem-bark was determined against three pathogenic bacterial strains E. coli, Salmonella typhi and Klebsiellia. pneumonia using disc diffusion method as reported by various authors [16, 19]. The extract was dissolved using methanol $(\mathrm{MeOH})$ and sterilized by filtration and stored at $4^{\circ} \mathrm{C}$ until use. Standard antibiotics (tetracycline) were used for comparison of the zone of inhibition of the pure strains of the bacteria. The extracts were then screened for their antibacterial activity against the bacterial strains. Set of four dilutions for antibacterial activity $(50,100,200,400$ $\mu \mathrm{g} / \mathrm{mL}$ ) of the stem bark of Barringtonia asiatica and standard drug tetracycline disc was used. Sterile plates containing Mueller-Hinton agar incubated with bacterial strains and control experiment using tetracyline as 
standard drug were kept for $3 \mathrm{hrs}$ at $37^{\circ} \mathrm{C}$. The set up was allowed for 18 to $24 \mathrm{hrs}$ at $37^{\circ} \mathrm{C}$, and the zones of growth inhibition around the disks were measured in $\mathrm{mm}$. The antibacterial activity of the test organisms on the plant extracts were determined by measuring the diameter of the inhibitory zones on the surface of the agar around the disk. The experiment was carried out in triplicate and the mean values of the diameter of zones of inhibition were calculated using statistical software SPSS 22.

\section{Statistical Analysis}

All results were expressed as Mean + SD. Data was analyzed statistically by one-way analysis of variance (ANOVA). The significance of the difference between the means of test and control studies was established and $P$ values less than 0.05 were considered significant.

\section{Physical Properties and Spectrometry Information of Pure Compounds}

Compound 1 (Nerolidol): Nerolidol (1); Yellow; melting point 20-21 ${ }^{\circ} \mathrm{C}$; IR $\mathrm{V}_{\max } \mathrm{cm}^{-1}$ : 3331, 1650, 1383, 879; MS $m / z$ (\% rel. int): 45(1), 55 (45), 57(5), 69(100), 79(18), 93(60), 97 (5), 107 (40), 119 (8), 136(10), 148 (2), 161 (5), 189 (1), 222 (1): ${ }^{1} \mathrm{H}-\mathrm{NMR}\left(500 \mathrm{MHz}, \mathrm{CDCl}_{3}\right) \delta(\mathrm{ppm})$ : 5.13; 5.17, (H-1), 5.89 (H-2), 1.38;1.63 (H-4), $2.00(\mathrm{H}-5)$, 5.26 (H-6), 1.89 (H-8), 2.23 (H-9), 5.27 (H-10), 1.53 (H12), 1.54 (H-13), $1.61(\mathrm{H}-14), 1.38(\mathrm{H}-15) .{ }^{13} \mathrm{C}-\mathrm{NMR}(500$ $\mathrm{MHz}_{\mathrm{CDCl}}$ ): $\delta(\mathrm{ppm}): 112.25(\mathrm{C}-1), 139.33(\mathrm{C}-2), 70.48(\mathrm{C}-$ 3), 41.53(C-4),21.89(C-5), 124.10 (C-6), 133.79 (C-7), 38.66 (C-8), 26.41 (C-9), 124.12 (C-10), 130.69 (11), 24.97 (12), 17.26 (13), 15.73 (14), 28.05 (15).

Compound 2 (Heneicosane): Heneicosane (2) yellow; melting point $40-41{ }^{\circ} \mathrm{C}$; IR $\mathrm{V}_{\max } \mathrm{cm}^{-1}$ : 2973, 1650, 2882, 1458, 879; MS $m / z$ (\% rel. int): 40(5), 41 (12), 43 (65), 57 (100), 71 (70), 85 (55), 99 (30), 113 (15), 127 (10), 141 (10), 155(5), 169 (2), 183 (2), 197 (1), 211 (1), 225 (1), 239(1), 253 (1), $267(1), 281$ (1), 296(1), 309 (1), 323 (1),
337(1), 350(1), 365(1), 379(1), 393(1), 407(1), 426(1), 440(1), 460(1), 479(1) 493(1): ${ }^{1} \mathrm{H}-\mathrm{NMR}$ (500 MHz, $\mathrm{CDCl}_{3}$ ) $\delta$ (ppm): 0.89 (7H, m, H-1/H-21), 1,26 (37H, s, H-2-H-20). ${ }^{13} \mathrm{C}-\mathrm{NMR}\left(500 \mathrm{MHz}, \mathrm{CDCl}_{3}\right): \delta(\mathrm{ppm}): 14.22(\mathrm{C}-1 / \mathrm{C}-21)$, 22.75(C-2/C-20), 31.89(C-3/C-19), 2938(C-4/C-18), 29.63(C-5-C-17).

\section{Result and Discussion}

\section{Purification and Structural Elucidation of Secondary Metabolites}

Purification of Compounds 1 and 2 from Dichloromethane Crude Stem-bark Extract of Barringtonia asiatica.

\begin{tabular}{|c|c|}
\hline Solvent & Volume to volume ratio (v/v) \\
\hline Hexane & 1 \\
\hline Hexane: DCM & $1: 1$ \\
\hline Hexane: DCM & $1: 2$ \\
\hline DCM & 1 \\
\hline DCM: $\mathrm{CHCl}_{3}$ & $1: 1$ \\
\hline${\mathrm{DCM}: \mathrm{CHCl}_{3}}$ & $1: 2$ \\
\hline $\mathrm{CHCl}_{3}$ & 1 \\
\hline $\mathrm{CHCl}_{3:} \mathrm{EA}$ & $1: 1$ \\
\hline $\mathrm{CHCl}_{3:} \mathrm{EA}$ & $1: 2$ \\
\hline $\mathrm{EA}$ & 1 \\
\hline $\mathrm{EA}: \mathrm{MeOH}$ & $1: 1$ \\
\hline $\mathrm{EA}: \mathrm{MeOH}$ & $5: 1$ \\
\hline $\mathrm{MeOH}$ & 1 \\
\hline
\end{tabular}

Table 2: Solvent systems used as eluting solvents for column chromatography (300 mL each solvent).

DCM: dichloromethane, $\mathrm{CHCl}_{3}$ : chloroform; EA: ethyl acetate; $\mathrm{MeOH}$ : methanol

Different fractions collected were labelled as BASB1 to BASB10 as shown in Table 4.3 and were further examined separately.

\begin{tabular}{|c|c|c|}
\hline Code of Fraction & Weight of Fraction (mg) & Colour of Fraction \\
\hline BASB1 & 6.18 & Colourless \\
\hline BASB2 & 12.39 & Colourless \\
\hline BASB3 & 34.7 & Light yellow \\
\hline BASB4 & 189.4 & Light yellow \\
\hline BASB5 & 118.2 & Brown \\
\hline BASB6 & 245.8 & Brown \\
\hline BASB7 & 182.9 & Dark brown \\
\hline BASB8 & 344.3 & Dark brown \\
\hline BASB9 & 325.9 & Dark brown \\
\hline BASB10 & 289.7 & Dark brown \\
\hline
\end{tabular}

Table 3: Fractions collected from dichloromethane stem-bark extract of Barringtonia asiatica. 
Purification and Structural Elucidation of Compound 1

Purification: Compound 1 was isolated from combined fraction BASB9 of $325.9 \mathrm{mg}$ Dark brown color. The TLC analysis of the combined fraction BASB9 was carried out in different solvent system. It was observed under UV light and recorded as shown in Table 2.

\begin{tabular}{|c|c|c|}
\hline Solvent system (v/v) & Number of spots & $\mathbf{R}_{\mathbf{f}}$ values \\
\hline \multirow{2}{*}{ Hexane: DCM (6:4) } & 2 & 0.32 \\
& 2 & 0.11 \\
\hline \multirow{2}{*}{ Hexane: $\mathrm{CHCl}_{3}$ (8:2) } & 2 & 0.42 \\
& 2 & 0.51 \\
\hline \multirow{2}{*}{ Hexane: EA (5:1) } & 2 & 0.28 \\
\end{tabular}

Table 4: $R_{f}$ values of combined fraction BASB9 in different solvent system under UV light.

The TLC subjected to UV a light yellow coloured spot with the same $\mathrm{Rf}$ value was observed and collected and combined from fraction BASB9-1 to BASB9-9. The combined fraction was labeled BASB9-D and subjected to a smaller column and combined fraction of BASB9-D2 was obtained. The TLC of BASB9-D2 was performed in the solvent system hexane: chloroform 8:2 which gave a good separation from the other spots present.

\begin{tabular}{|c|c|c|}
\hline Solvent system (v/v) & Number of spots & $\mathbf{R}_{\mathbf{f}}$ values \\
\hline \multirow{2}{*}{ Hexane: $\mathrm{CHCl}_{3}$ (8:2) } & 2 & 0.62 \\
& 2 & 0.44 \\
\hline \multirow{2}{*}{ Hexane: EA (8:2) } & 2 & 0.63 \\
& & 0.39 \\
\hline
\end{tabular}

Table 5: $\mathrm{R}_{\mathrm{f}}$ values of combined fraction BASB9-D2 in different solvent system under UV light.

The targeted spot combined and labeled as BASB9-D3 was again re-columned in smaller column using solvent system of Hexane: ethyl acetate (9:1) the TLC of BASB9D3 observed single spot and renamed BASB9-D4.

\begin{tabular}{|c|c|c|}
\hline Solvent system (v/v) & Number of spots & $\mathbf{R}_{\mathbf{f}}$ values \\
\hline Hexane: $\mathrm{CHCl}_{3}$ (9:1) & 1 & 0.49 \\
\hline
\end{tabular}

Table 6: $\mathrm{R}_{\mathrm{f}}$ values of combined fraction BASB9-D4 in different solvent system under UV light.

Figure 2: shows the TLC profile for the combined fraction BASB9-D4 in hexane: EA (9:1) as a single spot which suggest that it is a pure compound.

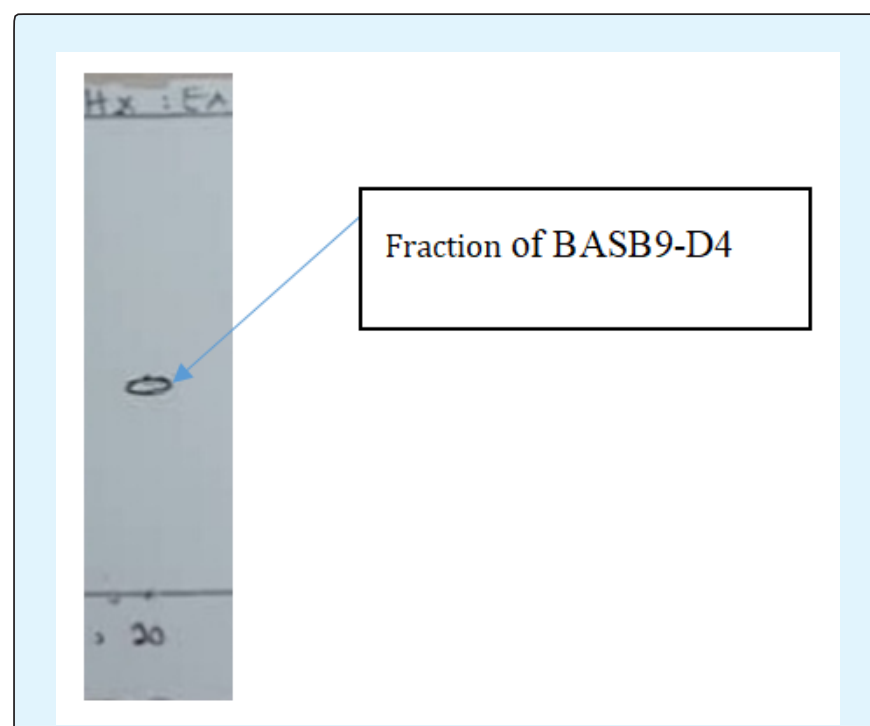

Figure 2: TLC plate showing the spot in fraction of BASB9-D4 in hexane: EA (9:1).

The Gas Chromatography (GC) analysis of the combined fraction BASB9-D4 was then carried out, and the result from the gas chromatogram Figure 2 showed a single peak at a retention time of 15.722 min. This confirmed that BASB9-D4 is a pure compound and it was renamed as Compound 1

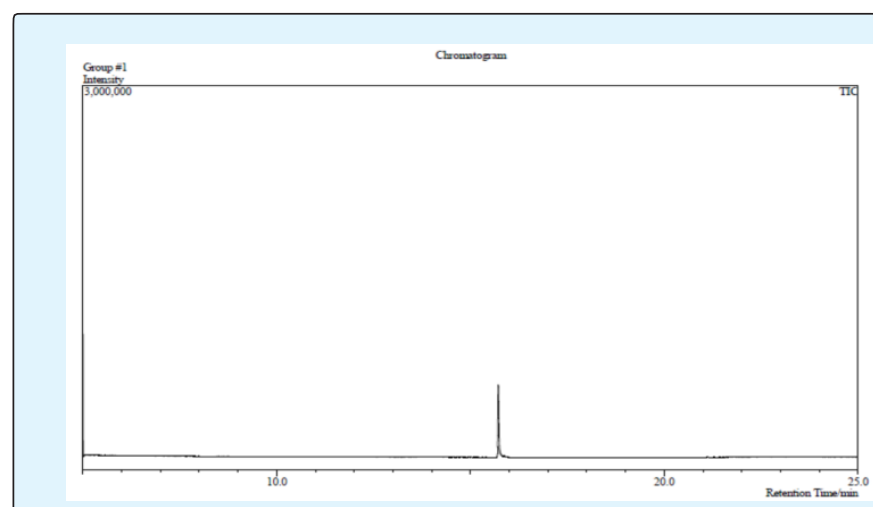

Figure 3: Gas chromatogram of Compound 1.

Structural Elucidation: Compound 1 was isolated from the DCM stem-bark extract of Barringtonia asiatica, with its physical appearance as a white crystal and a melting point at $20-21^{\circ} \mathrm{C}$. The mass spectrum of Compound 1 in Figure 4 shows a similarity index of $99.9 \%$ with the mass spectrum of the suggested structure of Compound 1 by the NIST library in Figure 4. On the mass spectrum of Compound 1 one of its molecular ion peaks was observed at $\mathrm{m} / z 222$ which was found to correspond to the 
molecular ion peak and molecular ion weight of the suggested structure of Compound 1 by the NIST library which has a chemical formula of $\mathrm{C}_{15} \mathrm{H}_{26} \mathrm{O}$. Figure 4 also shows base peak for Compound 1 at $m / z 69$ which was observed in the mass spectrum of the suggested structure for Compound 1.

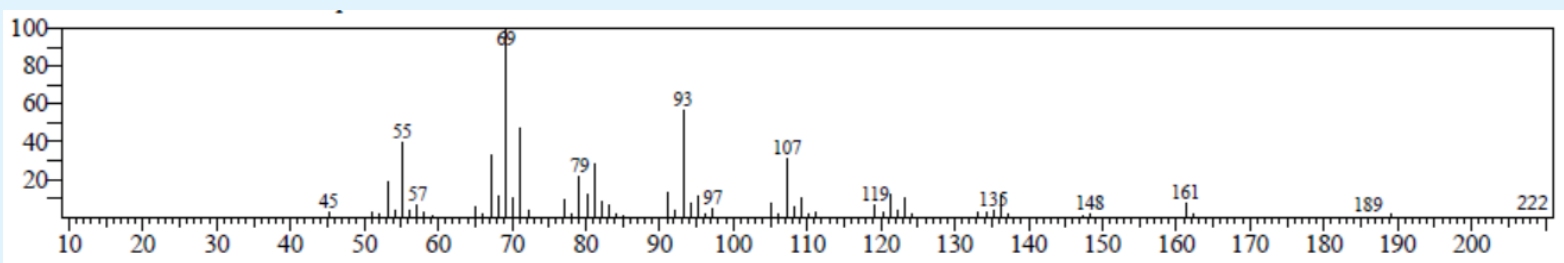

Figure 4: Mass spectrum of Compound 1.

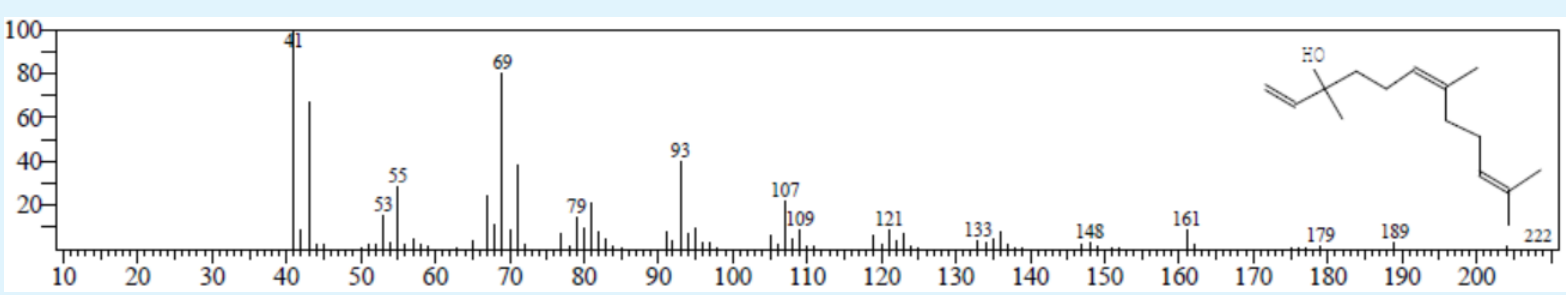

Figure 5: Mass spectrum of suggested structure of Compound 1 by NIST Library.

Chemical structure of Compound 1 consists of absorption bands of functional group of $\mathrm{OH}$ which was observed at $3331 \mathrm{~cm}^{-1}$ in the IR spectrum which represents the hydroxyl of Compound 1. A signal indicating the presence of double bond was observed at $1650 \mathrm{~cm}-1$ which Matched the three double bonds of $\mathrm{C}=\mathrm{C}$ in the structure. A Single Bond C-H stretching was observed at $1383 \mathrm{~cm}^{-1}$, and single bond of $=\mathrm{C}$ - $\mathrm{H}$ stretching at $879 \mathrm{~cm}^{-1}$ were observed in the IR spectrum of Compound 1, Figure 5. IR spectrum of Compound 1 also showed similarity to IR of the same proposed compound reported by Ferreira Farias, et al. [20].

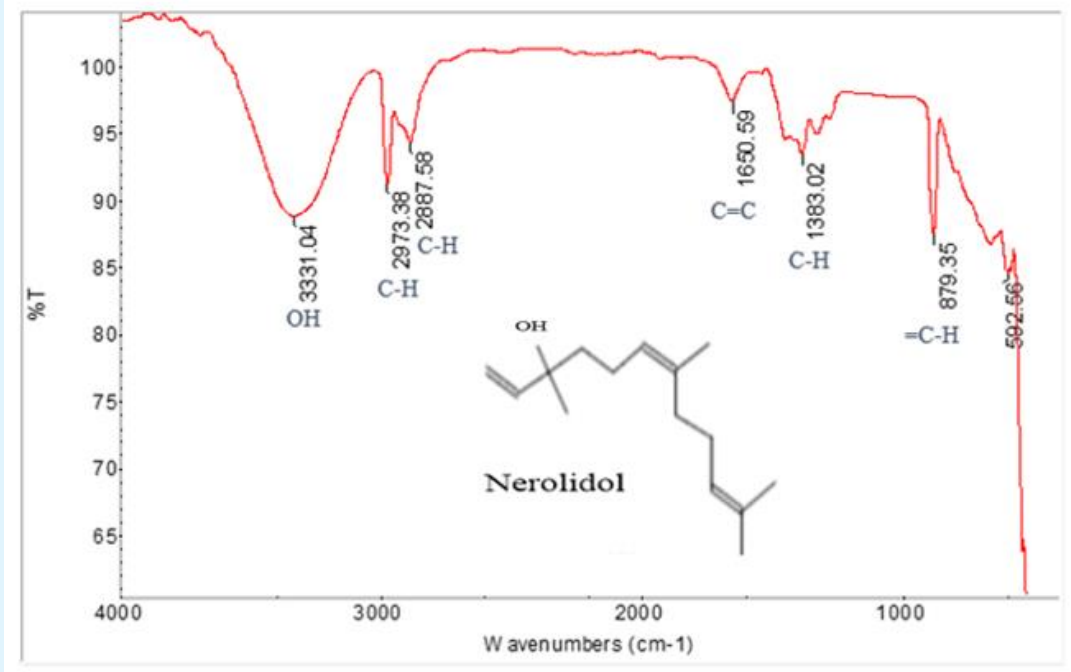

Figure 6: IR Spectrum of Compound. 
NMR analysis was further performed for the elucidation of the chemical structure of Compound 1, and the results are shown in Table $6\left({ }^{1} \mathrm{H}-\mathrm{NMR}\right)$ and Table 7 $\left.{ }^{13} \mathrm{C}-\mathrm{NMR}\right)$. Based on the table of ${ }^{1} \mathrm{H}-\mathrm{NMR}$ characteristics absorption and ${ }^{1} \mathrm{H}-\mathrm{NMR}$ peaks splitting pattern as reported in Organic Chemistry by Janice [13], the proton signals were all integrated and were assigned to every proton NMR of Compound 1 as the proposed chemical structure.

The result showed that ${ }^{1} \mathrm{H}-\mathrm{NMR}$ spectrum of Compound 1 exhibited 12 proton resonates. The proton signals were observed at $\delta 5.13, \delta 5.17$ and $\delta 5.89$ indicating the presence of ethylene proton in the structure, therefore assigned to $\mathrm{H}-1$ and $\mathrm{H}-2$ respectively, also observed are proton at $\delta 5.28$ and $\delta 5.29$ a trans methylene assigned to H-6 and H-10. Hydroxyl signal proton was observed at $\delta 4.76$ which represent the alcohol group in the structure. Four methyl proton signal was observed at $(\delta 1.38, \delta 1.63), \delta 1.89$ and $\delta 1.61$ and assigned to $\mathrm{H}-4, \mathrm{H}-8$ and $\mathrm{H}-14$. Another proton signal was observed at $\delta 1.53, \delta 2.00, \delta 1.54$ and $\delta 2.23$ can be seen to indicate the existence of methylene group and were assigned to $\mathrm{H}-12, \mathrm{H}-5, \mathrm{H}-13$ and $\mathrm{H}-9$ respectively.

Table 7 shows the result of the ${ }^{13} \mathrm{C}$-NMR result of Compound 1. From the result every carbon was assigned to the proposed chemical structure of Compound 1 which is based on the table of ${ }^{13} \mathrm{C}-\mathrm{NMR}$ characteristics absorption report in organic chemistry by Janice [13].

Fifteen carbon resonances were observed in the spectrum. The down field region showed five signals at $\delta$ $112.25, \delta 134.33, \delta 124.10, \delta 133.79, \delta 124.12$ and $\delta 130.69$ which were identified as ethylene carbons and were assigned to C-1, C-2, C-6, C-7, C-10 and C-11 respectively. Another signal observed at $\delta 70.48$ was assigned to $\mathrm{C}-3$ which was identified as $\mathrm{OH}$ group. Seven signals appeared at the up field region, two signals at $\delta 41.53, \delta 21.89$, $\delta 38.66, \delta 26.41, \delta 24.97, \delta 17.26, \delta 15.73$ and $\delta 28.05$ which indicated the presence of aliphatic carbons and were assigned to C-4, C-5, C-8, C-9, C-12, C-13, C-14 and C15 , respectively.

The chemical shift of every proton and carbon NMR for Compound 1 is as shown in Table 6 and Table 7 and comparison with NMR data of similar compound reported by Ferreira Farias et al., (2019). Thus, from the data obtained, the GCMS analysis of Compound 1 gave similarity index of $99.9 \%$ with the mass spectrum of the proposed compound by the NIST library which matched the characteristic of Nerodiol (1), with chemical formula $\mathrm{C}_{15} \mathrm{H}_{26} \mathrm{O}$. The melting point of Compound 1 is $20-21^{\circ} \mathrm{C}$. Also, mass spectrum of Compound 1 is similar to the mass spectrum of the suggested structure by NIST library and is most probably identified as Nerodiol (1), IR data reported by Ferreira Farias, et al., [20] could be seen to match the IR data of Compound 1 which was reported as Nerodiol (1).

Based on mass spectrum, IR, ${ }^{1} \mathrm{H}-\mathrm{NMR}$ and ${ }^{13} \mathrm{C}-\mathrm{NMR}$ data and comparison with published literature [20], Compound 1 was therefore identified as Nerodiol (1).

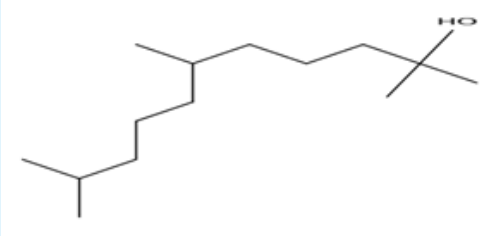

Nerolidiol (1)

\begin{tabular}{|c|c|c|c|}
\hline $\begin{array}{c}\text { Proton assigned to } \\
\text { Compound 1 }\end{array}$ & $\begin{array}{c}\text { Proton chemical shift (ppm) of } \\
\text { compound 1 }\end{array}$ & $\begin{array}{c}\text { Proton assigned to } \\
\text { Nerolidol [20] }\end{array}$ & $\begin{array}{c}\text { Proton chemical shift } \\
\text { (ppm) of Nerolidol [20] }\end{array}$ \\
\hline H-1 & $5.13 ; 5.17$ & $\mathrm{H}-1$ & $5.086 ; 5.017$ \\
\hline $\mathrm{H}-2$ & 5.89 & $\mathrm{H}-2$ & 5.86 \\
\hline $\mathrm{H}-3$ & - & $\mathrm{H}-3$ & - \\
\hline $\mathrm{H}-4$ & $1.38 ; 1.63$ & $\mathrm{H}-4$ & $1.382 ; 1.623$ \\
\hline $\mathrm{H}-5$ & 2 & $\mathrm{H}-5$ & 2.034 \\
\hline $\mathrm{H}-6$ & 5.26 & $\mathrm{H}-6$ & 5.277 \\
\hline $\mathrm{H}-7$ & - & $\mathrm{H}-7$ & - \\
\hline $\mathrm{H}-8$ & 1.89 & $\mathrm{H}-8$ & 1.894 \\
\hline $\mathrm{H}-10$ & 2.23 & $\mathrm{H}-9$ & 2.229 \\
\hline $\mathrm{H}-11$ & 5.27 & $\mathrm{H}-10$ & - \\
\hline $\mathrm{H}-12$ & - & $\mathrm{H}-11$ & - \\
\hline & 1,53 & $\mathrm{H}-12$ & 1,530 \\
\hline
\end{tabular}

Isaac John Umaru, et al. Isolation and Characterization of New Compound and its Antibacterial Activities from Stem-Bark Extract of Barringtonia Copyright $@$ Isaac John Umaru, et al. Asiatica. Ann Adv Biomed Sci 2019, 2(2): 000140. 


\section{Annals of Advanced Biomedical Sciences}

\begin{tabular}{|c|c|c|c|}
\hline $\mathrm{H}-13$ & 1.54 & $\mathrm{H}-13$ & 1.53 \\
\hline $\mathrm{H}-14$ & 1.61 & $\mathrm{H}-14$ & 1.604 \\
\hline $\mathrm{H}-15$ & 1.38 & $\mathrm{H}-15$ & 1.382 \\
\hline
\end{tabular}

Table 7: Proton NMR signal of compound 1 and that reported by Ferreira Farias, et al. [20].

\begin{tabular}{|c|c|c|c|}
\hline $\begin{array}{c}\text { Carbon assigned to } \\
\text { Compound 1 }\end{array}$ & $\begin{array}{c}\text { Carbon chemical shift (ppm) of } \\
\text { compound 1 }\end{array}$ & $\begin{array}{c}\text { Carbon assigned to Nerolidol by } \\
\text { Ferreira Farias, et al. [20]. }\end{array}$ & $\begin{array}{c}\text { Carbon chemical shift } \\
\text { (ppm) of Nerolidol [20] }\end{array}$ \\
\hline C-1 & 112.25 & C-1 & 11.54 \\
\hline C-2 & 139.33 & C-2 & 144.86 \\
\hline C-3 & 70.48 & C-3 & 73.01 \\
\hline C-4 & 41.53 & C-4 & 41.91 \\
\hline C-5 & 21.89 & C-5 & 22.61 \\
\hline C-6 & 124.1 & C-6 & 124.09 \\
\hline C-7 & 133.79 & C-7 & 134.63 \\
\hline C-8 & 38.66 & C-8 & 39.46 \\
\hline C-10 & 26.41 & C-9 & 26.41 \\
\hline C-11 & 124.12 & C-10 & 124.13 \\
\hline C-12 & 130.69 & C-11 & 130.79 \\
\hline C-13 & 24.97 & C-12 & 25.55 \\
\hline C-14 & 17.26 & C-13 & 17.33 \\
\hline C-15 & 15.73 & C-14 & 15.66 \\
\hline C & 28.05 & C-15 & 27.31 \\
\hline
\end{tabular}

Table 8: Carbon NMR signals of compound 1 and that reported by Nerolidol.

Nerolidiol (1) a sesquiterperpene alcohol is a major active constituent of many herbal plants and has demonstrated many beneficial pharmacological effects in vitro, including anti-inflammatory, antioxidant, it is also used as a flavoring agent and perfumery as well as detergents and cleaners [21].

\section{Purification and Structural Elucidation of Compound} 2

Purification: Compound 2 was isolated from the combined fraction BASB7 of Barringtonia stem-bark extract in DCM. TLC analysis of the combined fraction BASB7 was performed in different solvent systems and the result as observed under UV light was recorded as shown in Table 9.

\begin{tabular}{|c|c|c|}
\hline Solvent system (v/v) & Number of spots & $\mathbf{R}_{\mathbf{f}}$ values \\
\hline \multirow{2}{*}{ Hexane: $\mathrm{CHCl}_{3}$ (6:4) } & \multirow{2}{*}{3} & 0.59 \\
\cline { 3 - 3 } Hexane: EA (8:2) & \multirow{2}{*}{3} & 0.56 \\
\cline { 3 - 3 } & & 0.61 \\
\hline
\end{tabular}

Table 9: $\mathrm{R}_{\mathrm{f}}$ values of combined fraction BASB7in different solvent system under UV light.

The fractions containing a light yellowish spot were targeted and combined; it was labelled as BASB7-B.
Combined fraction BASB7-B was then further purified two successive times in a smaller column using the solvent system hexane: ethyl acetate (8:2), and each fraction collected (BASB7-B1 and BASB7-B2) were observed under UV light and those containing the light yellowish spot were combined and labelled as BASB7-B3. Combined fraction of BASB7-B3 was then tested using TLC and observed under UV light. The result is shown in Table 10.

\begin{tabular}{|c|c|c|}
\hline Solvent system (v/v) & Number of spots & $\mathbf{R}_{\mathbf{f}}$ values \\
\hline \multirow{2}{*}{ Hexane: EA (8:2) } & \multirow{2}{*}{2} & 0.60 \\
\cline { 3 - 3 } & & 0.62 \\
\hline \multirow{2}{*}{ DCM: EA (7:3) } & \multirow{2}{*}{2} & 0.57 \\
\cline { 3 - 3 } & & 0.69 \\
\hline
\end{tabular}

Table 10: $\mathrm{R}_{\mathrm{f}}$ values of combined fraction BASB7-B3 in different solvent system under UV light.

Combined fraction BASB7-B3 was further purified using small column and fractions containing the targeted spots from BASB7-B3 were then combined and labelled as BASB7-B3a. Combined fraction BASB7-B3a was further purified using the solvent system DCM: EA (7:3), which gives a better separation. TLC of the fractions collected was performed and examined under UV light. Fractions containing the target spots were combined and labelled as BASB7-B3a1. TLC of the combined fraction BASB7- 
B3a1was performed in different solvent system and the result was again examined under UV light and vanillin staining. It showed a single sport as shown in Table 11.

\begin{tabular}{|c|c|c|c|}
\hline $\begin{array}{c}\text { Combined } \\
\text { fraction }\end{array}$ & $\begin{array}{c}\text { Solvent system } \\
\text { (v/v) }\end{array}$ & $\begin{array}{c}\text { Number } \\
\text { of spots }\end{array}$ & $\mathbf{R}_{\mathbf{f}}$ values \\
\hline BASB7-B3a1 & Hexane: EA (7:3) & 1 & 0.63 \\
\hline
\end{tabular}

Table 11: $\mathrm{R}_{\mathrm{f}}$ values of combined fraction BASB7-B3a1 in different solvent system under UV light.

Figure 5 shows the TLC profile for the combined fraction BASB7-B3a1 in DCM: EA (7:3) as a single spot which suggest that it is a pure compound.

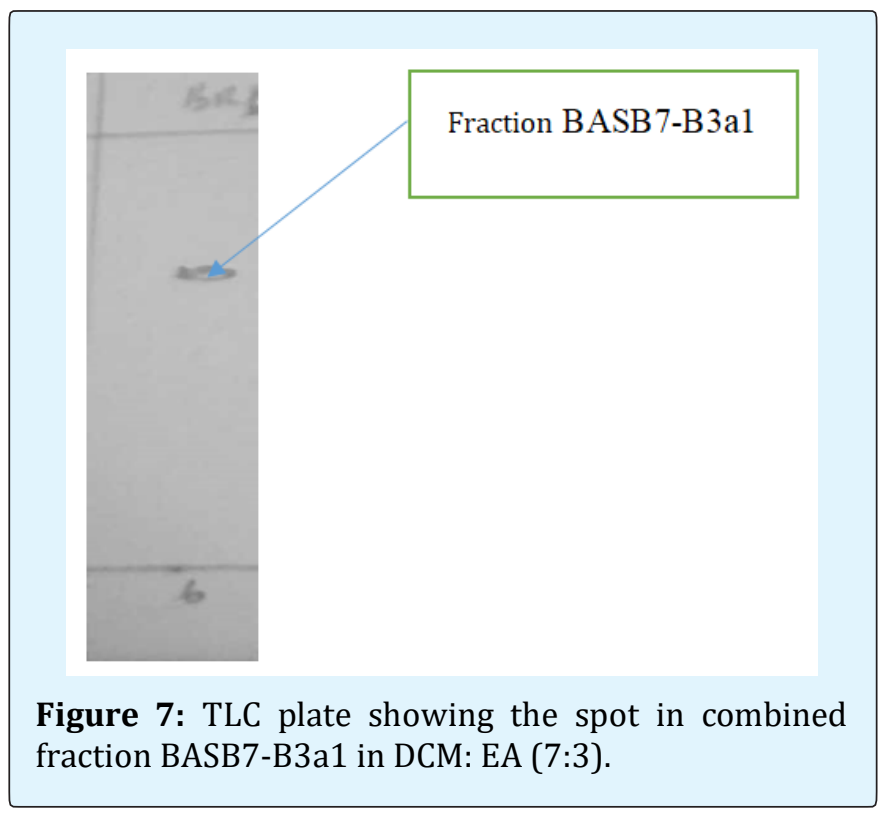

The combined fraction BASB7-B3a1 as shown in Figure 5 is considered a pure compound. Gas chromatography (GC) analysis of the fraction BASB7-B3a1 was then carried out, and the result showed a single peak at a retention time of $27.657 \mathrm{~min}$. This confirmed that BASB7-B3a1 is a pure compound and it was renamed as Compound 2. It is a light yellowish compound and $18 \mathrm{mg}$ was obtained.

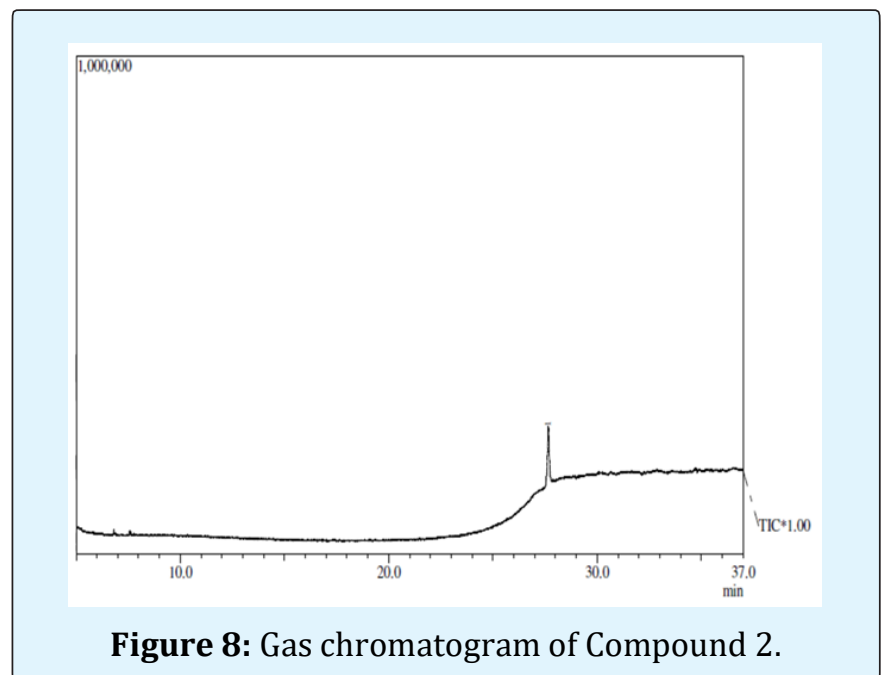

Structural Elucidation: The isolated Compound physical appearance as a light yellow compound with a melting point $40-41{ }^{\circ} \mathrm{C}$ was observed. The mass spectrum of Compound 2 as shown in Figure 7 indicated a similarity index of $99.9 \%$ with the mass spectrum of the compound suggested by the NIST library in Figure 8. The mass spectrum of Compound 2 showed an ion base peak which was observed at $\mathrm{m} / \mathrm{z} 57$ and a molecular ion peak of $\mathrm{m} / \mathrm{z}$ 57 was also observed in the mass spectrum of the suggested structure of Compound 2. The mass spectrum of Compound 2 has one of its molecular ion peaks observed at $m / z 296$, this corresponded to the same molecular ion peak and molecular ion weight of the suggested structure of Compound 2 by NIST library with a chemical formula of $\mathrm{C}_{21} \mathrm{H}_{44}$.

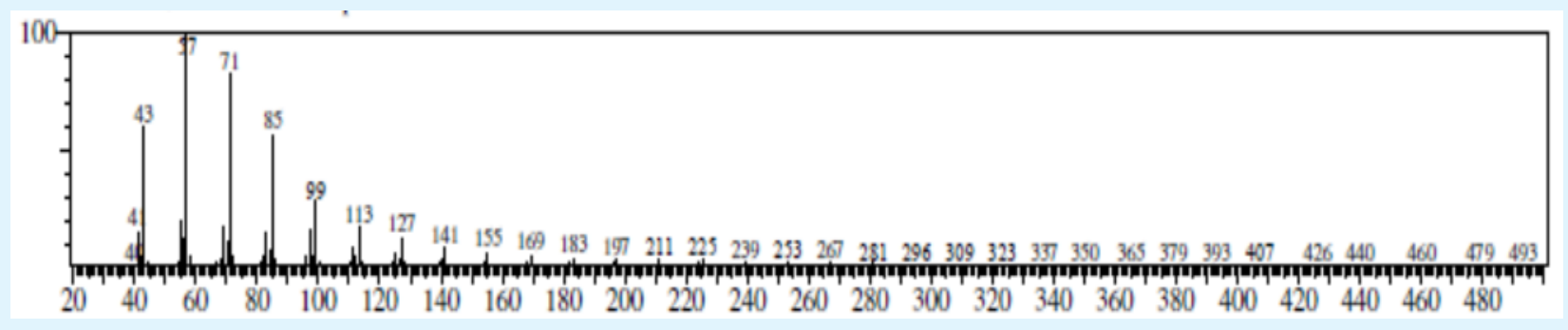

Figure 9: Mass spectrum of Compound 2. 


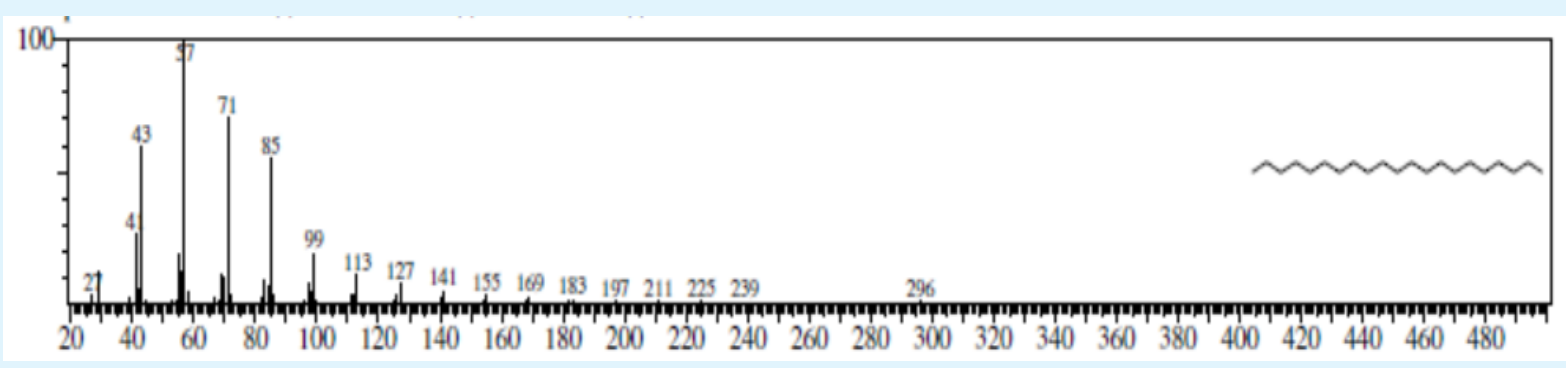

Figure 10: Mass spectrum of suggested structure of Compound 2 by NIST library.

The chemical structure of Compound, an absorption band of $\mathrm{C}-\mathrm{H}$ was observed at $2973 \mathrm{~cm}^{-1}$ which indicated the presence of methyl group in the chemical structure. A signal was observed at $2882 \mathrm{~cm}^{-1}$ which indicated the presence of C-H bond. At $1458 \mathrm{~cm}^{-1}$ a signal was observed which matched the methyl group of $\mathrm{C}-\mathrm{H}$ in the suggested structure. Single bond C-C stretching was observed at 879 $\mathrm{cm}^{-1}$ in the IR spectrum of compound 2 . The spectrum is transparent in the $1480 \mathrm{~cm}-1-1850 \mathrm{~cm}-1$, and 4000-3000 $\mathrm{cm}-1$ region indicating the absence of $\mathrm{C}=\mathrm{C}$. the compound suggested therefore indicated to be an alkane type [22].

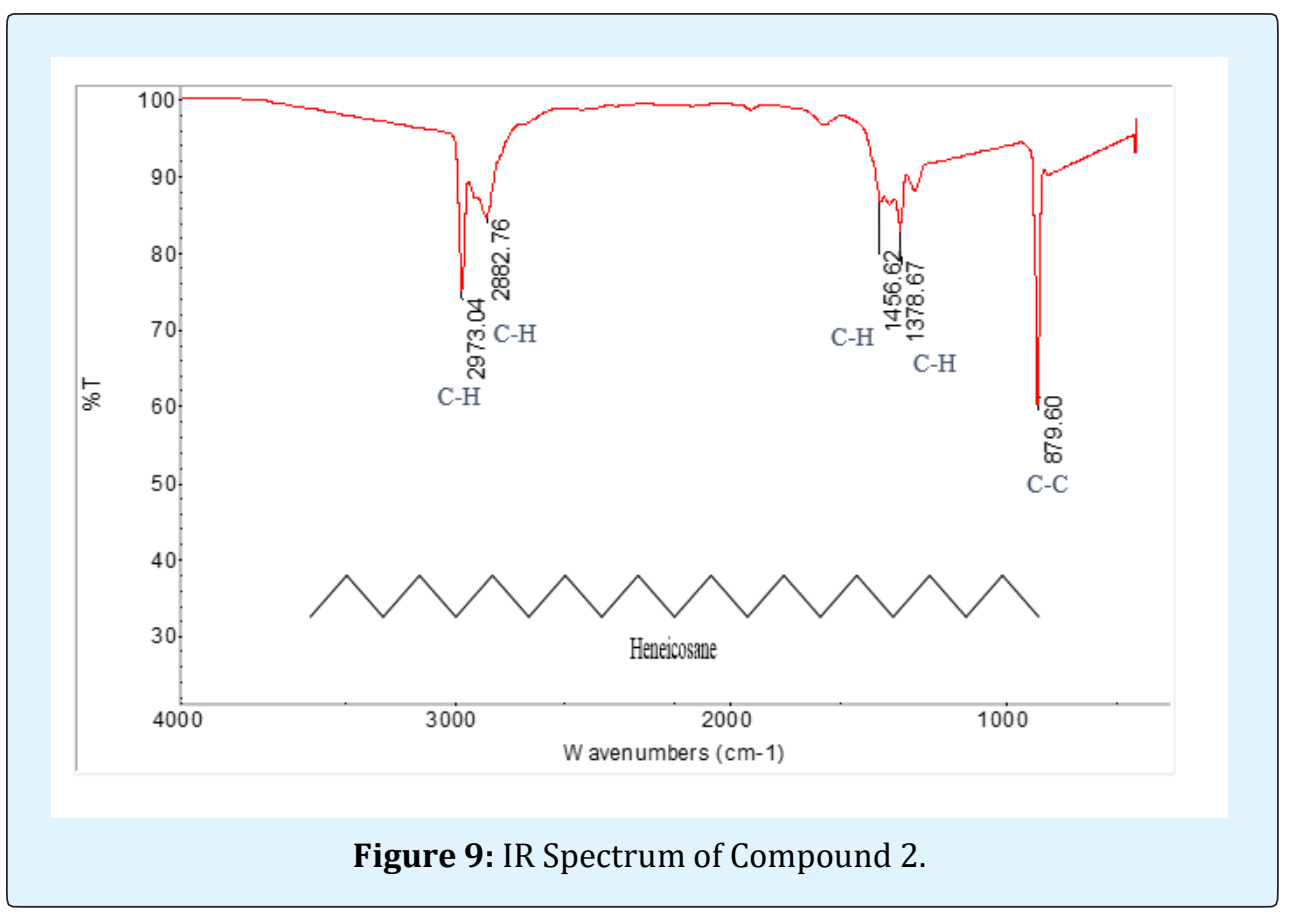

NMR analysis was further performed for the elucidation of the chemical structure of Compound 2 and the results are shown in Table $11\left({ }^{1} \mathrm{H}-\mathrm{NMR}\right)$ and Table 12 $\left({ }^{13} \mathrm{C}-\mathrm{NMR}\right)$. Based on the table of ${ }^{1} \mathrm{H}-\mathrm{NMR}$ characteristics absorption and ${ }^{1} \mathrm{H}-\mathrm{NMR}$ peaks splitting pattern as reported in Organic Chemistry by Janice [13], the proton signals were all integrated and were assigned to every proton NMR of Compound 2 as the proposed chemical structure.
The ${ }^{1} \mathrm{H}-\mathrm{NMR}$ spectrum of Compound 2 exhibited 2 proton resonates. A singlet proton signal was observed at $\delta 1.26(37 \mathrm{H}, \mathrm{s})$ indicating the presence of methylene broad signal centered at $\delta 1.26$. Of the structure and was assigned to $\mathrm{H}-2-\mathrm{H}-20$. A singlet proton signal was observed at $\delta 0.89(7 \mathrm{H}, \mathrm{m})$ indicating the presence of a methyl group and was assigned to $\mathrm{H}-1 / \mathrm{H}-21$. A singlet proton signals observed corresponds with a methyl group of the suggested structure. 
The ${ }^{13} \mathrm{C}$-NMR spectrum of Compound 2 exhibited 21 carbon resonates, at the up field region, signals were observed at $\delta 22.75, \delta 31.89, \delta 29.38$ and $\delta 29.63$ are aliphatic carbon which indicated the presence of methine were assigned to $\mathrm{C}-1 / 21, \mathrm{C}-2 / 20, \mathrm{C}-3 / 19, \mathrm{C}-4 / 18$ and $\mathrm{C}-5-$
17. A methylene groups for $\delta 14.22$, of the structure were assigned to $\mathrm{C}-1 / \mathrm{C}-21$, respectively. This indicated the presence of methyl and methylene in the suggested and similar compound reported by Suparna, et al. [22].

\begin{tabular}{|c|c|c|c|}
\hline $\begin{array}{c}\text { Proton assigned to } \\
\text { Compound 1 }\end{array}$ & $\begin{array}{c}\text { Proton chemical shift } \\
\text { (ppm) of compound 1 }\end{array}$ & $\begin{array}{c}\text { Proton assigned to Heneicosane by } \\
\text { Suparna, et al. [22] }\end{array}$ & $\begin{array}{c}\text { Proton chemical shift (ppm) } \\
\text { of Heneicosane [22] }\end{array}$ \\
\hline $\mathrm{H}-1 / \mathrm{H}-21$ & $0.89(7 \mathrm{H}, \mathrm{m})$ & $\mathrm{H}-1 / \mathrm{H}-21$ & $0.88(3 \mathrm{H}, \mathrm{m})$ \\
\hline $\mathrm{H}-2-20$ & $1.26(37 \mathrm{H}, \mathrm{s})$ & $\mathrm{H}-2-20$ & $1.26(\mathrm{~s})$ \\
\hline
\end{tabular}

Table 12: Proton NMR signals of compound 1 and that reported by Suparna, et al. [22].

\begin{tabular}{|c|c|c|c|}
\hline $\begin{array}{c}\text { Carbon assigned to } \\
\text { Compound 2 }\end{array}$ & $\begin{array}{c}\text { Carbon chemical shift } \\
\text { (ppm) of compound 2 }\end{array}$ & $\begin{array}{c}\text { Carbon assigned to Heneicosane by } \\
\text { Suparna, et al. [22] }\end{array}$ & $\begin{array}{c}\text { Carbon chemical shift (ppm) } \\
\text { of Heneicosane [22] }\end{array}$ \\
\hline C-1/21 & 14.22 & C-1 & 14.12 \\
\hline C- $2 / 20$ & 22.75 & C-2 & 22.71 \\
\hline C-3/19 & 31.89 & C-3 & 31.96 \\
\hline C-4/18 & 29.38 & C-4 & 29.39 \\
\hline C-5-17 & 29.63 & C-5 & 29.73 \\
\hline
\end{tabular}

Table 13: Carbon NMR signals of compound 1 and that reported by Suparna, et al. [22].

The data obtained for Compound 2, and the GC spectrum which was identified as Heneicosane) (2) gave similarity index $99.9 \%$ with the mass spectrum of the proposed sructure by the NIST library, which matched the characteristic of Heneicosane (2) with chemical formula $\mathrm{C}_{21} \mathrm{H}_{44}$. The proton and carbon NMR data of Compound 2 were mostly identical to match the NMR signal of Heneicosane (2) as reported by Suparna, et al. [22].

Based on mass spectrum, IR, ${ }^{1} \mathrm{H}-\mathrm{NMR}$ and ${ }^{13} \mathrm{C}-\mathrm{NMR}$ data and comparison with published literature [22] Compound 2 was identified as Heneicosane (2).

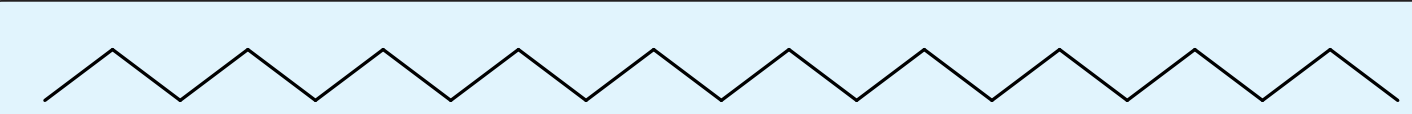

Heneicosane (2)

Heneicosane (2) is a compound that found active against some resistance pathogens, it inhibited by all concentrations of heneicosane. The effect is much pronounced in Pseudomonas aeruginosa and Sarcina lutea, as well as Staphylococcus aureus, Pseudomonas aeruginosa, and Sarcina lutea [22].

\section{Biological activity of Norolidol (1) and Heneicosane (2)}

The biological activity of the new compound from Barringtonia asiatica stem-back extract Norolidol (1) and Heneicosane (2) is as shown in Table 14 and Figure 10. The activity of Nerolidol and Heneicosane against this selected bacterial was significant when compared to the test control at all the concentration tested. Higher growth inhibition rate was observed at $100 \mathrm{ppm}$ though significant inhibition was observed in all the test bacteria as shown in figure 10. The maximum inhibition of Nerolidol (1) on Escherichia coli, Klebsiella pneumonia, were found at $50 \mathrm{ppm}$ of $5.15 \pm 0.08 \mathrm{~mm}$, and $10.67 \pm 0.06$ $\mathrm{mm}$, while Salmonella typhi at $100 \mathrm{ppm}$ of $11.04 \pm 0.06$ $\mathrm{mm}$. weaker inhibition was observed at $25 \mathrm{ppm}$ of $3.89 \pm 0.14 \mathrm{~mm}, 2.87 \pm 0.12 \mathrm{~mm}$ and $8.00 \pm 0.07 \mathrm{~mm}$ when compared to the test control.

Heneicosane (2) activity was found to be more active on the bacterial when compared to Nerolidol with the highest rate of inhibition observed at $50 \mathrm{ppm}$ and 100 ppm of $10.54 \pm 0.03 \mathrm{~mm}, 9.97 \pm 0.04 \mathrm{~mm}, 11.76 \pm 0.02 \mathrm{~mm}$ and $11.98 \pm 0.07 \mathrm{~mm}, 11.87 \pm 0.03 \mathrm{~mm}, 12.17 \pm 0.03 \mathrm{~mm}$, respectively as shown in Table 13. Generally, the entire isolated pure compound showed a significant rate of 
inhibition growth on all the selected pathogen. Thus, pathogens. these agents could be used as a remedy against resistance
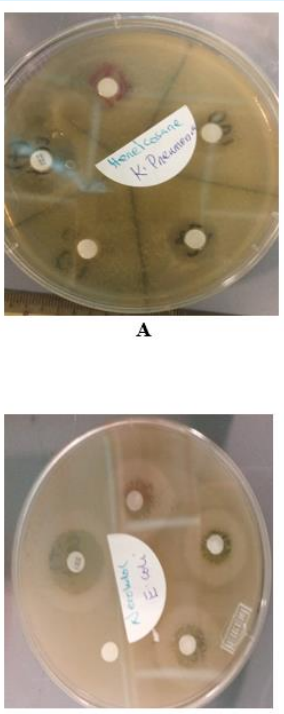

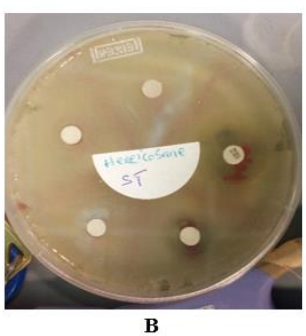

B

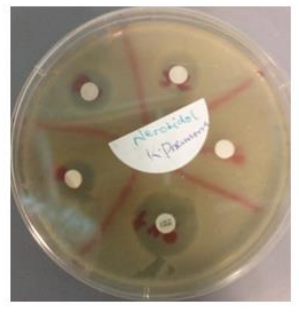

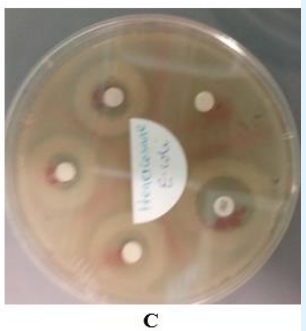

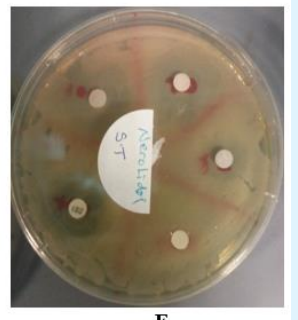

Figure 10: Showing the inhibition growth rate of Nerolidiol (D, E, F) and Heneicoasane (A, B, F) of Escherichia coli, Klebsiella pneumonia, and Salmonella typhi.

\begin{tabular}{|c|c|c|c|c|c|}
\hline \multicolumn{7}{|c|}{ Concentration (ppm) } \\
\hline \multirow{3}{*}{ Isolated Compound } & \multirow{2}{*}{ Organism } & $\begin{array}{c}\text { Control } \\
\text { (Tetracycline) }\end{array}$ & $\mathbf{2 5} \mathbf{~ p p m}$ & $\mathbf{5 0} \mathbf{~ p p m}$ & $\mathbf{1 0 0} \mathbf{~ p p m}$ \\
\cline { 2 - 6 } & & $\mathbf{( m m )}$ & $\mathbf{( m m})$ & $\mathbf{( m m})$ & $\mathbf{( m m})$ \\
\hline \multirow{3}{*}{ Nerolidiol $(\mathbf{1})$} & Escherichia coli & $13.25 \pm 0.41$ & $3.89 \pm 0.14$ & $5.15 \pm 0.08$ & $4.50 \pm 0.11$ \\
\hline \multirow{3}{*}{ Heneicosane $(\mathbf{2})$} & Klebsiella pneumonia & $12.90 \pm 0.13$ & $2.87 \pm 0.12$ & $10.67 \pm 0.06$ & $7.96 \pm 0.12$ \\
\cline { 2 - 6 } & Salmonella typhi & $13.20 \pm 0.05$ & $8.00 \pm 0.07$ & $9.89 \pm 0.05$ & $11.04 \pm 0.06$ \\
\hline & Escherichia coli & $13.08 \pm 0.06$ & $10.09 \pm 0.03$ & $10.54 \pm 0.03$ & $9.97 \pm 0.04$ \\
\cline { 2 - 6 } & Klebsiella pneumonia & $12.89 \pm 0.17$ & $6.85 \pm 0.04$ & $11.76 \pm 0.02$ & $11.98 \pm 0.07$ \\
\cline { 2 - 6 } & Salmonella typhi & $13.25 \pm 0.16$ & $9.36 \pm 0.06$ & $11.87 \pm 0.03$ & $12.17 \pm 0.03$ \\
\hline
\end{tabular}

Table 14: The biological activity of the new compound from Barringtonia asiatica stem-back extract Norolidol (1) and Heneicosane (2).

Result is in Mean $\pm \mathrm{SD}$. $\mathrm{N}=3$. $^{*}=$ significant activity was observed

Figures are in $\mathrm{mm}$ and include the diameter of the paper disc $(5 \mathrm{~mm})$. Data are means of triplicate determinations.

\section{Conclusion}

In the following study, we obtained the following results, the chemical constituent from Stem-bark extract of Barringtonia asiatica isolate on the bases of spectral analysis it was confirmed that compound 1 and 2 are Nerolidol (1) and Heneicosne (2). The biological activity of these compounds was observed to possess interesting biological activity. They were found to be active against the bacterial tested and may have potential to be developed as antibacterial agents. However, these compounds were isolated for the first time of Stem-bark extract of Barringtonia asiatica.

\section{Acknowledgement}

The authors wish to acknowledge the research grant 07(ZRC05/1238/2015(2) provided by Universiti Malaysia Sarawak which has resulted to this article. 


\section{Conflict of Interest}

The authors declare no competing of interest.

\section{Funding}

This work was supported by the Universiti Malaysia Sarawak (research grant; 07(ZRC05/1238/2015(2).

\section{References}

1. Wakawa H, Hauwa M (2013) Protective effect of Erythrina senegalensis (DC) leaf extract on carbon tetrachloride-induced liver injury in rats. Asian Journal of Biological Sciences 6(4): 234-238.

2. Rosenthal GA, Janzen DD (1979) Herbivores; their interaction with plant secondary metabolites. Academic Press, New York.

3. Soepadmo E (1999) Botanical study of Malaysian medicinal plants. In: Manaf FA, (Ed.), An appraisal: phytochemicals and biopharmaceutins from Malaysian rain forest, FRIM, Kuala Lumpur, pp: 1-14.

4. Khairana H, Nozaima MK, Jamia Azdini J, Juriyati J, Ibrahim J (2006) Ethnobotanical Survey on Malaysian Medicinal Plants used as Anticancer Agents. In: Fasihhudin BA, Zaini A, Laily B Din, Ikram MS, (Eds.), Malaysian medicinal plants. Chemistry and biological activity. Universiti Malaysia Sarawak, Lee Meng Press, Kuching, pp: 63-75.

5. Raphael EC (2011) Traditional medicine in Nigeria: current status and the future. Research Journal of Pharmacology 5(6): 90-94.

6. Ntie Kang F, Mbah JA, Mbaze LM, Lifongo LL, Scharfe $M$, et al. (2013) Cam Med NP: Building the Cameroonian 3D structural natural products database for virtual screening. BMC Complementary Alternative Medicine 13: 88-96.

7. Fasihuddin BA, Sallehuddin Nur Khairun NM, Assim Z (2010) Chemical constituents and antiviral study of Goniothalamus velutinus. Malaysian Journal of Fundamental and Applied Sciences 6(1): 73-76.

8. Isaac John Umaru, Fasihuddin A Badruddin, Hauwa A Umaru (2018) Antioxidant Properties and Antibacterial Activities of Leptadenia Hastata Leaves Extracts on Staphylococcus Aureus. Drug Designing \&
Intellectual Properties International Journal 1(5): 131-135.

9. Firdous AM, Fayaz AL, Mushtaq AS (2013) Isolation of active components derived from rhizome of Euphorbia wallichii Hook. International Journal of Ayurvedic and Herbal Medicine 3(3): 1173-1183.

10. Patra JK, Gouda S, Sahoo SK, Thatoi HN (2012) Chromatography separation, ${ }^{1} \mathrm{H}$ NMR

11. Isaac John Umaru, Fasihuddin Badruddin Ahmad, Hauwa A Umaru (2019) Extraction, Elucidation, Characterization and Evaluation of Antibacterial Activity of Four Pure Compound from Barringtonia racemosa Leaf Extract. World Journal of Pharmacy and Pharmaceutical Sciences 8(8): 184-223

12. Shalini S, Sampathkumar P (2012) Phytochemical screening and antimicrobial activity of plant extracts for disease management. International Journal of Current Science 1(1): 209-218.

13. Janice GS (2008) Key concepts-Mass spectrometry, infrared spectroscopy and nuclear magnetic resonance spectroscopy. Organic Chemistry, McGrawHill, New York, pp: 485-525.

14. Efdi M, Fujita S, Inuzuka T, Koketsu M (2010) Chemical studies on Goniothalamus tapis Miq. Natural Product Research 24(7): 657-662.

15. McLaughlin JL, Rogers LL, Anderson JE (1998) The use of biological assays to evaluate botanicals. Drug Information Journal 32(2): 513-524.

16. Isaac John Umaru, Fasihuddin A Badruddin, Zaini B Assim, Hauwa A Umaru (2018) Cytotoxicity (Brine shrimp Lethality Bioassay) of Barringtonia racemosa Leaves, Stem-Bark and Root Extract. Journal of Biotechnology and Bioengineering 2(2): 1-6.

17. Wang HX, Liu CM, Liu Q, Gao K (2008) Three types of sesquiterpenes from rhizomes of Atractylodes lancea. Phytochemistry 69(10): 2088-2094.

18. Tailor CS, Goyal A (2014) Antioxidant activity by DPPH radical scavenging method of Ageratum conyzoides Linn. Leaves. American Journal of Ethno medicine 1(4): 244-249.

19. Prashanth VK, Chauhan NS, Padh H, Rajani M (2006) Search for antibacterial and antifungal agents from 
selected Indian medicinal plants. Journal of Ethno pharmacology 107(2): 182-188.

20. Ferreira Farias AL, Lobato Rodrigues $A B$, Lopes Martins R, de Menezes Rabelo É, Ferreira Farias CW, et al. (2019) Chemical Characterization, Antioxidant, Cytotoxic and Microbiological Activities of the Essential Oil of Leaf of Tithonia Diversifolia (Hemsl) A. Gray (Asteraceae). Pharmaceuticals 12(1): 34.

21. Chan WK, Tan L, Chan KG, Lee LH, Goh BH (2016) Nerolidol: a sesquiterpene alcohol with multi-faceted pharmacological and biological activities. Molecules 21(5): 529.

22. Suparna MB, Nabanita C, Prasanta CB (2017) Cutcular wax of Tectona grandis L. Leaves-AR Against plant pathogens. Biochemistry and Analytical Biochemistry 6(3): 1-6.

23. Siddiqui BS, Rasheed M, Ilyas F, Gulzar T, Tariq RM, et al. (2004) nalysis of insecticidal Azadirachta indica A. Juss. fractions. Zeitschrift für Naturforschung C 59(12): 104-112. 